\title{
EFEKTIVITAS MENYIKAT GIGI DENGAN METODE BASS DAN HORIZONTAL TERHADAP PERUBAHAN INDEKS PLAK PADA ANAK TUNAGRAHITA
}

\author{
Nabila Rizkika*, Moh. Baehaqi**, R. Rama Putranto***
}

\begin{tabular}{c}
\hline Keywords: \\
bass method, \\
horizontal method, \\
plaque index, \\
children with mental \\
retardation \\
\hline
\end{tabular}

\section{ABSTRACT}

Background: The important aspect for child especially children with mental retardation is oral health. Children with mental retardation have limitations in motoric activities that relate to the actions of dental hygiene in normally, that activities is toothbrushing and it can do by bass and horizontal method. The aim of this study is to know the difference effectiveness toothbrushing with bass and horizontal method on the changed of plaque index in children with mental retardation. Method: The quasi experimental methods with non-equivalent group design with post test design was used in this research and have done on 24 children with mild mental retardation at SDLB Purwosari Kudus which divided two groups, 12 students brushing with bass method and 12 students brushing with horizontal method. Result: The data were tested with paired t-test to compare plaque index before and after toothbrushing with bass and horizontal method, showed that there were meaningful differences $(p<0,05)$. Independent t-test to compare the changed of plaque index between both methods, showed that there were no meaningful differences $(p>0,05)$. Conclusion: It concluded that both bass and horizontal method effectively on the changed of plaque index in children with mental retardation. There was no difference effectiveness between both methods.

\section{PENDAHULUAN}

Gigi memiliki peranan penting terhadap pertumbuhan anak, antara lain sebagai alat pengunyahan makanan, membantu melumatkan makanan dalam mulut dan berfungsi dalam membantu alat pencernaan sehingga makanan dapat diserap tubuh dengan baik ${ }^{1}$. Seorang anak dikatakan sehat jika kebersihan mulutnya terjaga. Jika kebersihan mulut tidak terjaga maka akan timbul berbagai permasalahan pada gigi seperti gigi berlubang atau karies ${ }^{2}$.

Prevalensi karies di Indonesia masih cenderung tinggi, yakni $90,90 \%$, dimana penyebab utama karies adalah adanya akumulasi plak berkaitan dengan kebersihan mulut yang buruk ${ }^{3,4}$. Plak merupakan lapisan lunak yang terdiri dari $80 \%$ air dan $20 \%$ sisanya merupakan komponen seperti protein, lipid, dan komponen mineral yakni kalsium dan fosfor ${ }^{5}$.

Upaya untuk membersihkan plak dapat dilakukan dengan cara menyikat gigi6. Menyikat gigi dapat dilakukan melalui beberapa metode, diantaranya adalah metode bass dan horizontar. Teknik bass merupakan teknik meyikat gigi yang dilakukan dengan meletakkan sikat gigi 45 derajat pada akar gigi lalu tekan perlahan sambil dilakukan gerakan berputar kecil. Metode horizontal dilakukan dengan mengarahkan sikat gigi bergerak maju mundur ${ }^{8}$.

Kebiasaan menyikat gigi sebaiknya sudah diperkenalkan kepada anak-anak sejak dini ${ }^{6}$. Kesulitan melaksanakan prosedur membersihkan mulut secara benar ditemukan pada anak usia dibawah 5 tahun dan juga pada anak dengan 
ketidakmampuan mental $^{9}$. Anak dengan ketidakmampuan mental atau dikenal dengan tunagrahita memiliki keterbatasan dalam memfungsikan diri, penyesuaian diri dengan lingkungan ${ }^{10}$.

Prevalensi karies yang lebih tinggi 30\% dibanding anak normal dan kebersihan mulut yang buruk merupakan masalah yang dihadapi anak tunagrahita ${ }^{11,12}$. Kekurangan dalam motivasi dan kemampuan berkonsentrasi membuat anak tunagrahita sulit dalam melakukan kegiatan yang berhubungan dengan tindakan kebersihan gigi ${ }^{11}$. Penelitian terdahulu menyebutkan bahwa pada anak normal dengan usia 9-10 tahun didapatkan bahwa metode horizontal lebih efektif dalam penurunan indeks plak jika dibandingkan dengan metode ro/l13.

Penelitian ini bertujuan untuk mengetahui perbedaan efektivitas menyikat gigi dengan metode bass dan horizontal terhadap perubahan angka indeks plak pada anak tunagrahita.

\section{METODE PENELITIAN}

Penelitian ini adalah penelitian quasy experimentaldengan rancangan penelitian non equivalent group with posttest design yang dilakukan di SDLB Purwosari Kudus. Sampel yang digunakan merupakan populasi sampel, yakni seluruh populasi anak tunagrahita dengan klasifikasi ringan sebanyak 24 anak. Sampel kemudian dibagi menjadi dua kelompok, yaitu 12 anak kelompok menyikat gigi metode bass dan 12 anak kelompok menyikat gigi metode horizontal. Pada masingmasing kelompok diberi pengetahuan tentang kesehatan gigi dan mulut serta teknik menyikat gigi yang benar sesuai metode yang digunakan dalam waktu yang berbeda, kemudian seluruh sampel diinstruksikan untuk berlatih metode menyikat gigi sesuai yang telah diajarkan dengan pengawasan orang tua dalam waktu satu minggu. Setelah satu minggu kemudian dilakukan pengukuran indeks plaks yang pertama, kemudian masingmasing kelompok diinstruksikan untuk menyikat gigi sesuai metode yang telah diajarkan dengan durasi waktu yang sama. Setelah itu dilakukan pengukuran indeks plak yang kedua.

Data hasil penelitian ini selanjutnya di uji normalitas dengan Shapiro-Wilk untuk mengetahui apakah sampel berasal dari populasi yang terdistribusi normal. kemudian untuk membedakan perubahan

\begin{tabular}{|c|c|c|c|}
\hline \multicolumn{2}{|c|}{ Sebelum Perlakuan } & \multicolumn{2}{|c|}{ Sesudah Perlakuan } \\
\hline Kriteria & Jumlah & Kriteria & Jumlah \\
\hline Baik & 0 & Baik & 0 \\
\hline Sedang & 3 & Sedang & 8 \\
\hline Buruk & 9 & Buruk & 4 \\
\hline
\end{tabular}

Tabel 1. Distribusi frekuensi kriteria indeks plak menyikat gigi metode bass

\begin{tabular}{cc|cc}
\hline \multicolumn{2}{c|}{ Sebelum } & Perlakuan & \multicolumn{2}{c}{ Sesudah } & Perlakuan \\
\hline Kriteria & Jumlah & Kriteria & Jumlah \\
\hline Baik & 0 & Baik & 1 \\
Sedang & 2 & Sedang & 9 \\
Buruk & 10 & Buruk & 2 \\
\hline
\end{tabular}

Tabel 2. Distribusi frekuensi kriteria indeks plak menyikat gigi metode horizontal 


\begin{tabular}{cccccc}
\hline Kelompok & $\mathrm{N}$ & Mean \pm SD & \multicolumn{3}{c}{ Hasil Uji Statistic } \\
& & & $\mathrm{t}$ & $\mathrm{df}$ & $\mathrm{P}$ \\
\hline Sebelum & 12 & $3,88 \pm 0,51$ & & & \\
\hline Sesudah & 12 & $3,03 \pm 0,55$ & & \multirow{2}{*}{11} & \multirow{2}{*}{0,000} \\
\hline
\end{tabular}

Tabel 3. Rata-rata indeks plak sebelum dan sesudah menyikat gigi dengan metode bass

\begin{tabular}{cccccc}
\hline \multirow{2}{*}{ Kelompok } & \multirow{2}{*}{$\mathrm{N}$} & Mean $\pm \mathrm{SD}$ & \multicolumn{4}{c}{ Hasil Uji Statistic } \\
& & & $\mathrm{t}$ & $\mathrm{df}$ & $\mathrm{P}$ \\
\hline Sebelum & 12 & $3,73 \pm 0,49$ & \multirow{2}{*}{7,402} & \multirow{2}{*}{11} & 0,000 \\
\hline Sesudah & 12 & $2,90 \pm 0,53$ & & & \\
\hline
\end{tabular}

Tabel 4. Rata-rata indeks plak sebelum dan sesudah menyikat gigi dengan metode horizontal

\begin{tabular}{|c|c|c|c|c|c|}
\hline \multirow{2}{*}{ Kelompok } & \multirow{2}{*}{$\mathrm{N}$} & \multirow{2}{*}{ Mean \pm SD } & \multicolumn{3}{|c|}{ Hasil Uji Statistic } \\
\hline & & & $\mathrm{T}$ & $\mathrm{df}$ & $\mathrm{p}$ \\
\hline Bass & 12 & $0,84 \pm 0,51$ & 071 & 22 & 0.044 \\
\hline Horizontal & 12 & $0,83 \pm 0,38$ & & & \\
\hline
\end{tabular}

Tabel 5. Rata-rata selisih indeks plak sebelum dan sesudah menyikat gigi antara 2 metode

angka indeks plak sebelum dan sesudah perlakuan menyikat gigi dengan metode bass dan horizontal dilakukan uji paired t-test, kemudian dilakukan uji independent t-test untuk membandingkan perubahan angka indeks plak setelah mendapat perlakuan menyikat gigi dengan metode bass dan horizontal

\section{HASIL PENELITIAN}

Data yang ditunjukkan pada tabel 1 dan 2 menunjukkan terdapat perubahan indeks plak sebelum dan sesudah menyikat gigi dengan metode bass dan horizontal . Hasil uji paired t-test pada tabel 3 menunjukkan nilai $p$ sebesar 0,000 dan nilai ini di bawah $0,05(p<0,05)$ sehingga dapat dikatakan terdapat perbedaan yang bermakna antara indeks plak sebelum dan sesudah perlakuan menyikat gigi dengan metode bass, dimana rata-rata indeks plak sebelum adalah 3,88 dan sesudah perlakuan 3,03.

Pada tabel 4 dengan uji paired t-test didapatkan $p$ nilai $p$ sebesar 0,000 dan nilai ini di bawah $0,05(p<0,05)$ sehingga dapat dikatakan terdapat perbedaan yang bermakna antara indeks plak sebelum dan sesudah perlakuan menyikat gigi dengan metode horizontal, dimana ratarata indeks plak sebelum adalah 3,73 dan sesudah perlakuan 2,90.

Hasil analisis statistik dengan uji beda independent t-test pada tabel 5 menunjukkan tidak terdapat perbedaan perubahan angka indeks plak yang bermakna antara menyikat gigi dengan metode bass dan horizontal pada anak tunagrahita $(p>0,05)$.

\section{DISKUSI}

Berdasarkan hasil penelitian didapatkan bahwa baik metode bass maupun horizontal efektif dalam perubahan angka indeks plak pada anak tunagrahita. Penelitian terdahulu menyebutkan bahwa menyikat gigi dengan metode horizontal lebih efektif dalam pengurangan plak 
dibanding metode roll pada anak normal dengan usia 9-10 tahun $^{13}$. Menyikat gigi dengan metode bass lebih efektif daripada teknik roll dalam pembersihan bagian margin gingiva dan sulkus ${ }^{14}$.

Hasil uji statistik pada penelitian ini menunjukkan tidak terdapat perbedaan yang bermakna antara metode bass dan horizontal dalam efektivitas perubahan angka indeks plak pada anak tunagrahita. Hasil tersebut sejalan dengan penelitian terdahulu yang membandingkan efektivitas metode horizontal scrub dan modified bass terhadap penurunan indeks plak pada anak tunanetra dan didapatkan hasil tidak berbeda ${ }^{13}$.

Tidak adanya perbedaan efektivitas yang bermakna diantara kedua metode dapat dikarenakan faktor dari anak tunagrahita. Anak tunagrahita sulit sekali berpikir abstrak, dalam belajar harus dikaitkan dengan objek yang bersifat kongkrit, mengalami kesulitan mengingat terutama ingatan jangka pendek, dan kesulitan dalam mentransfer pengetahuan yang sudah dimiliki pada situasi yang berbeda $^{15}$. Mereka mengalami kesulitan dalam merawat diri, salah satunya melakukan tindakan membersihkan gigi dan mulut karena adanya keterbatasan koordinasi motorik sehingga menghambat penderita retardasi mental untuk mengkoordinasikan gerakan tangan dan jari-jari dalam kegiatan menyikat gigi yang benar ${ }^{16}$.

Anak tunagrahita yang menjadi sampel pada penelitian ini adalah anak tunagrahita ringan. Anak tunagrahita ringan merupakan tunagrahita yang masih bisa dididik dan juga masih memiliki kemampuan persepsi yang baik tetapi pada umumnya mereka mengalami kesulitan untuk mengolah informasi, menyimpan dan menggunakan kembali informasi yang sebelumnya sudah disimpan ${ }^{17}$.

Kesulitan dalam merawat diri pada anak tunagrahita menyebabkan mereka memerlukan waktu yang lama, latihan dan bantuan yang lebih banyak serta pengajaran yang berulang-ulang untuk dapat melakukan suatu kegiatan dengan benar ${ }^{18}$. Hal ini juga yang menyebabkan mereka mengalami kesulitan dalam mempraktekkan metode menyikat gigi seperti yang telah diajarkan sebelumnya jika dibandingkan dengan anak normal.

Kesulitan dalam mempraktekkan metode menyikat gigi sesuai dengan yang telah diajarkan dapat dipengaruhi karena kesulitan anak tunagrahita dalam berpikir, berkonsentrasi dan memusatkan perhatian terhadap suatu informasi. Penggunaaan metode penyuluhan yang tepat dapat mempengaruhi kemampuan anak tunagrahita dalam menyerap informasi yang disampaikan.

Faktor lain yang dapat mempengaruhi hasil penelitian ini adalah orang tua. Anak tunagrahita membutuhkan dukungan sosial dari orang tua mereka, karena dengan dukungan tersebut akan membantu mereka untuk dapat melakukan kegiatan yang berhubungan dengan tindakan merawat diri19. Pengetahuan merupakan salah satu faktor dalam menentukan perilaku sehingga apabila pengetahuan orang tua tinggi maka praktek menyikat gigi pada anak juga bisa dilaksanakan dengan baik dan peran yang aktif dari orang tua akan menjadikan anak terbiasa melaksanakan menyikat gigi secara rutin ${ }^{20}$.

\section{KESIMPULAN}

Berdasarkan hasil penelitian didapatkan hasil menyikat gigi dengan metode bass dan horizontal efektif terhadap perubahan angka indeks plak pada anak tunagrahita. Tidak terdapat perbedaan efektivitas yang signifikan diantara kedua metode tersebut.

\section{DAFTAR PUSTAKA}

1. Thioritz, E. Pengaruh Faktor Sosial - 
Ekonomi Terhadap Status Karies Pada Murid Taman Kanak-Kanak Kec. Rappocini. Media Kesehatan Gigi, 2010, pg 43.

2. Paulus, K. Efek Klinis Pemakaian Obat Kumur Melia Propolid Terhadap Pertumbuhan Plak Pada Gigi Anak Usia 11-13 Tahun di Panti Asuhan Asshabirin Kota Makassar. Media Kesehatan Gigi, 2010, pg 6

3. Zulkarnain, R.A.A., Riyanti, E., Sasmita, I.S. The Differences of Caries Prevalence and Caries Index of Children in Primary School with UKSG in Kota Batam. Bandung. Padjajaran Journal of Dentistry, 2009, Vol. 21, No. 1, pg 36

4. Indirawati, T.N., S, Made, A.L., Delima., Ganni, L. Nilai Karies Gigi Anak Kelas 1 dan Kelas 6 Sekolah Dasar di Salah Satu Puskesmas Kabupaten Tangerang (Pemeriksaan Dokter Umum, Dokter Gigi dan Perawat Gigi). Jakarta. Bul. Penelit. Kesehat, 2010, Vol, 38, No. 2, pg 90

5. Harmely, F., Lucida, H., Mukhtar, M.H. Efektivitas Bromelain Kasar dari Batang Nenas (Ananas comosus L. Merr) sebagai Antiplak dalam Pasta Gigi. Sicentia, 2011, Vol. 1, No.1

6. Hermina, V. Efektivitas Metode Pengajaran Cara Menyikat Gigi Terhadap Penurunan Indeks Plak Anak Usia 3-5 tahun. Medan. Dentika Dental Journal, 2010, Vol. 15, No. 1 , pg 42

7. Putri, M.H., Herijulianti, N., Nurjannas, N. IImu Pencegahan Penyakit Jaringan Keras dan Jaringan Pendukung Gigi. EGC. Jakarta. 2010. pg 54-57, 98-99, 107-108, 113-114

8. Harris, N.O., Godoy, F.G., Nathe, C.N. (ed). Primary Preventive Dentistry. New Jersey. Pearson Education, 2009. pg 14, 131, 245

9. Angela, A. Pencegahan Primer Pada Anak yang Berisiko Karies Tinggi. Medan. Maj. Ked. Gigi, 2005, Vol. 38, No. 3, pg 132

10. Wardani, IG.A.K., Astati., Hernawati, T., Somad, P. Materi Pokok Pengantar Pendidikan Luar Biasa. Universitas Terbuka. Jakarta. 2009. pg 6.5

11. Stefanovska, E., Nakova, M., RadojkovaNikolovska, V.; Ristoska S. Tooth-Brushing Intervention Programme among Children with Mental Handicap. Bratisl Lek Listy, 2010, Vol. 111, No. 5, pg 299

12. Purohit, B.M., Singh, A. Oral Health Status of 12-year-old Children with Disabilities and Controls in Southern India. WHO South-East
Asia Journal of Public Health, 2012, Vol. 1, No. 3 , pg 337

13. Smutkeeree, A., Rojlakkanawong, N., Yimchaeron, U. A 6-month Comparison of Toothbrushing Efficacy The Horizontal Scrub and Modified Bass Methods in Visualy Impaired Students. Thailand. International Journal of Paediatric Dentistry, 2011, Vol. 21, pg 278-279, 282

14. Ferrera, M.P., Egea, J.S., Fernandez, P.B. Comparison of Modified Bass Technique with Normal Toothbrushing Practices for Efficacy in Supragingival Plaque Removal. Faculty of Dentistry Univercity of Seville Spain. Int J Dent Hygiene, 2003, Vol.1, pg 111

15. Palupi, D.R. Peningkatan Kualitas Pembelajaran Penjumlahan dan Pengurangan Melalui Pembelajaran Matematika Realistik Peserta Didik Tunagrahita Ringan SLB Pembina Malang. Diakses 3 September 2013. ejournal.umm.ac.id. 2012

16. Anggraeni, A., Soelarso, H., Martina, L. Peran Orang Tua/Pengasuh Terhadap Prevalensi Karies Molar Pertama Rahang Bawah Permanen Pada Anak-Anak Retardasi Mental. Surabaya. Dental Public Health Journal, 2010, Vol. 2, No. 2, pg 3

17. Sumaryanti., Kushartanti, W., Ambardhini, R.L. Pengembangan Model Pembelajaran Jasmani Adaptif Untuk Optimalisasi Otak Anak Tunagrahita. Yogyakarta. Jurnal Kependidikan, 2010, Vol. 40, No. 1, pg 31-32

18. Nurlailiwangi, E., Rahayu, M.S., Juwita, O. Studi Mengenai Dukungan Sosial Orang Tua Dalam Melatih "Self Help" Anak yang Mengalami "Down Syndrome" di PKA PUSPPA Suryakanti Bandung. Prosiding Seminar Nasional Penelitian dan PKM. 2011. Vol 2, No. $1, \mathrm{pg} 71$

19. Nurulistyawan, T.P., Sri, R. Pengetahuan dan Peran Orang Tua Tentang "Oral Hygiene" dengan Praktik Gosok Gigi pada Anak usia 6-12 Tahun di Desa Gondosari Kec. Gebog Kabupaten Kudus. Jurnal Keperawatan, 2008, Vol. 2, No. 1, pg 48

20. Agoes, A., Windarwati, H.D., Widyartaty, K. Hubungan Pemberian Motivasi Oleh Keluarga Terhadap Kemampuan Merawat Diri Pada Anak Tunagrahita Di SDLB Putra Jaya Malang. Diakses 25 Agustus 2013. www.fk.ub.ac.id. 2011 